\title{
Low temperature synthesis of magnesium doped cobalt ferrite nanoparticles and their structural properties
}

\author{
Vithal Vinayak $^{1}$, Pankaj P. Khirade ${ }^{2}$, Shankar D. Birajdar ${ }^{2}$, P.K.Gaikwad ${ }^{3}$, N.D.Shinde ${ }^{2}$, K.M.Jadhav ${ }^{2}$ \\ Department of Chemistry, B.S.S. Arts \& Science College, Makni, Tq:Lohara, Osmanabad (M.S.), India ${ }^{1}$ \\ Department of Physics, Dr. Babasaheb Ambedkar Marathwada University, Aurangabad (M.S.), India ${ }^{2}$ \\ Department of Physics, Chatrapati Shivaji College, Omerga, Osmanabad (M.S.), India ${ }^{3}$
}

\begin{abstract}
The present work focuses on the effect of magnesium $\left(\mathrm{Mg}^{2+}\right)$ substitution on structural studies of the nanocrystalline cobalt ferrite $\left(\mathrm{CoFe}_{2} \mathrm{O}_{4}\right)$. Nanosized magnesium doped cobalt ferrite powders with general formula $\mathrm{Co}_{1 \text { - }}$ ${ }_{\mathrm{x}} \mathrm{Mg}_{\mathrm{x}} \mathrm{Fe}_{2} \mathrm{O}_{4}$ (for $\mathrm{x}=0.0,0.50$ and 1.0) were synthesized by sol-gel auto combustion method starting from metal nitrates and citric acid $\left(\mathrm{C}_{6} \mathrm{H}_{8} \mathrm{O}_{7}\right)$ as a fuel. The prepared samples were sintered at $550{ }^{\circ} \mathrm{C}$ for $4 \mathrm{~h}$. The structural properties were estimated from X-ray diffraction (XRD) studies. The average particle size was calculated by using Debye Scherer's formula using XRD data and is obtained to be 11-24 nm. The bulk densities $\left(d_{B}\right)$ of all the samples were measured using Archimedes principle. The other structural parameters such as tetrahedral bond length $\left(\mathrm{d}_{\mathrm{AX}}\right)$, octahedral bond length $\left(\mathrm{d}_{\mathrm{BX}}\right)$, tetra edge $\left(\mathrm{d}_{\mathrm{AXE}}\right)$ and octa edge $\left(\mathrm{d}_{\mathrm{BXE}}\right)$ were calculated from XRD data.
\end{abstract}

Keywords: cobalt ferrite, nanocrystalline, sol-gel, XRD.

\section{INTRODUCTION}

In recent years, spinel ferrites have been investigated for their useful electrical and magnetic properties which can be used for different applications in information storage systems, sensors, catalysis, magnetic drug delivery, permanent magnets, recording heads, antenna rods, loading coils, telecommunication devices, magnetic refrigeration, magnetic liquids, as a microwave absorber [1-6]. Thus much interest has been taken on the synthesis and characterization of nanoparticles of spinel ferrites.

Many important properties of the spinel ferrites crucially depend on the exact nature of the cation distribution. It has been established that the unusual properties of the nanoferrites can be explained on the basis of the synthesis methods, nature and type of substituent, particle size, $\mathrm{pH}$, sintering temperature, etc. All these parameters can play a crucial role in the modification of the electrical and magnetic properties of spinel ferrites which can be useful for the desired applications.

For the applications of nanomaterials in various diverse fields [7-9], it is necessary to be designed and exploited new materials of more predictable properties than what are currently available. Cobalt ferrite $\left(\mathrm{CoFe}_{2} \mathrm{O}_{4}\right)$, owing to strong ferromagnetism and high Curie temperature, is used in electronic appliances since it stays magnetized even when the applied magnetic field is removed. This leads towards a useful way of information storage.

$\mathrm{Co}-\mathrm{Mg}$ nano-ferrite is an interesting material because of its high coercivity, moderate saturation magnetization, good chemical stability and mechanical hardness; therefore, it can found applications in magnetic drug delivery and high density information storage $[10,11]$.
The traditional ceramic technique to synthesize ferrites results in crystalline material but with lower surface area, higher sintering temperature etc. In order to avoid these disadvantages wet chemical methods are used.

The most widely used wet chemical method for the synthesis of spinel nanoferrites is the sol-gel auto combustion method due to its low processing temperature, high chemical homogeneity, the possibility of controlling the size and morphology of particles etc.

Cobalt ferrite $\left(\mathrm{CoFe}_{2} \mathrm{O}_{4}\right)$ with high magnetocrystalline anisotropy, high saturation magnetization, high electrical resistivity, high coercivity, is one of the best candidate among the other spinel ferrite for various applications. Cobalt ferrite can be used in many applications such as magnetic drug delivery, microwave devices, high density information storage, ferro-fluids etc [12, 13].

It has been observed that when cobalt ferrite substituted with cations like $\mathrm{Mn}, \mathrm{Zn}$, Ni etc, the properties of cobalt ferrite are modified [14-16]. Magnesium $\left(\mathrm{Mg}^{2+}\right)$ is a nonmagnetic ion and can modify the properties when substituted in cobalt ferrite.

Thus, the aim of the present work is to synthesize $\mathrm{Mg}^{2+}$ substituted cobalt ferrite via sol-gel auto combustion method and to investigate the structural and magnetic properties.

Here, we have focused on synthesis of $\mathrm{Co}_{1-\mathrm{x}} \mathrm{Mg}_{\mathrm{x}} \mathrm{Fe}_{2} \mathrm{O}_{4}$ (for $\mathrm{x}=0.0,0.50$ and 1.0 ) spinel ferrite nanocrystals via sol-gel auto combustion method and structural properties are reported herein. 


\section{EXPERIMENTAL}

\section{A. Preparation of $\mathrm{Co}_{1-x} \mathrm{Mg}_{x} \mathrm{Fe}_{2} \mathrm{O}_{4}$ Spinel Ferrite} Nanoparticles

The nanocrystalline samples of magnesium substituted cobalt ferrite $\left(\mathrm{Co}_{1-\mathrm{x}} \mathrm{Mg}_{\mathrm{x}} \mathrm{Fe}_{2} \mathrm{O}_{4}, \mathrm{x}=0.0,0.50\right.$ and 1.0) were prepared using sol-gel auto combustion method. AR grade chemicals such as cobalt nitrate $\left(\mathrm{Co}\left(\mathrm{NO}_{3}\right)_{2}\right)$, magnesium nitrate $\left(\mathrm{Mg}\left(\mathrm{NO}_{3}\right)_{2}\right)$, ferric nitrate $\left(\mathrm{Fe}\left(\mathrm{NO}_{3}\right)_{3}\right)$ and citric acid $\left(\mathrm{C}_{6} \mathrm{H}_{8} \mathrm{O}_{7}\right)$ were used for the synthesis. The metal nitrates to fuel (citric acid) ratio was taken as 1:3. Ammonia solution was added to maintain the $\mathrm{pH}$ 7. The temperature required for the synthesis of $\mathrm{Co}-\mathrm{Mg}$ nanoparticles was low that is around $110{ }^{\circ} \mathrm{C}$. The assynthesized powder is sintered at $550{ }^{\circ} \mathrm{C}$ for $4 \mathrm{~h}$ and then used for further investigations of structural properties. The detail of synthesis procedure is shown in flowchart below:

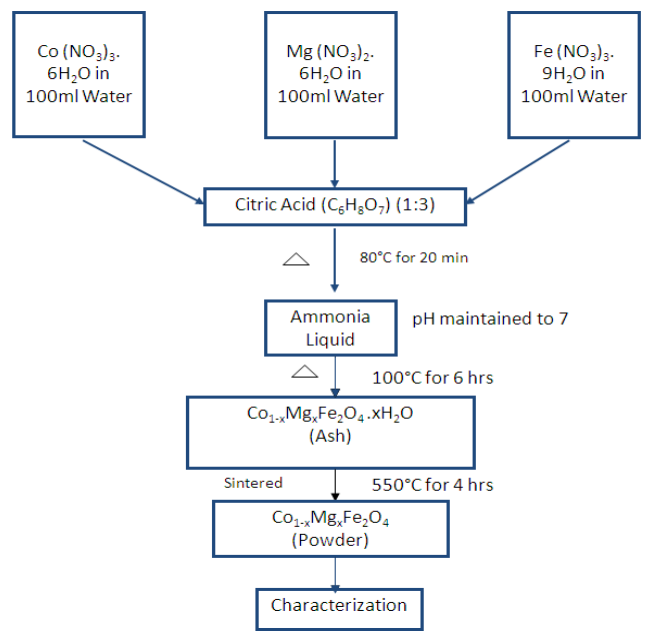

Fig. 1. Flowchart of sol-gel auto combustion synthesis of $\mathrm{Co}_{1-\mathrm{x}} \mathrm{Mg}_{\mathrm{x}} \mathrm{Fe}_{2} \mathrm{O}_{4}$

\section{B. Characterizations}

X-ray diffraction (XRD) technique was employed to characterize the prepared $\mathrm{Co}-\mathrm{Mg}$ nanoparticles using REGAKU X-ray diffractometer. The XRD patterns were recorded at room temperature in the $2 \theta$ range of $20^{\circ}$ to $80^{\circ}$ using $\mathrm{Cu}-\mathrm{K} \alpha$ radiation $(\lambda=1.54056 \AA)$.

\section{RESULTS AND DISCUSSIONS}

$X$-ray diffraction $(X R D)$

The typical X-ray diffraction pattern of the $\mathrm{Co}_{1-\mathrm{x}} \mathrm{Mg}_{\mathrm{x}} \mathrm{Fe}_{2} \mathrm{O}_{4}$ (for $\mathrm{x}=0.50$ ) spinel ferrite nanoparticles is shown in fig. 2.

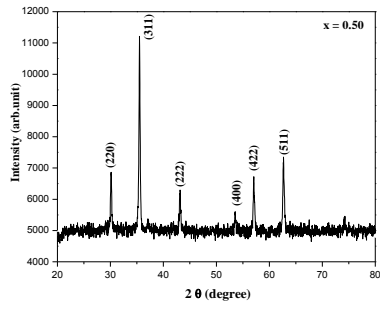

Fig. 2. XRD pattern of $\mathrm{Co}_{1-\mathrm{x}} \mathrm{Mg}_{\mathrm{x}} \mathrm{Fe}_{2} \mathrm{O}_{4}(\mathrm{x}=0.50)$

The XRD pattern shows the reflections belonging to cubic spinel structure; no extra peaks have been observed in the XRD patterns. The single phase formations of compounds Copyright to IARJSET

under investigations were confirmed from the analysis of XRD pattern. The intensity of (311) plane is more as compared to other planes like (220), (222), (400), (422), (511) and (440) and is chosen for the determination of crystallite size. Table 1 gives the planes (h k 1), corresponding Bragg's angles along with their interplanar spacing (d) values, intensity and intensity ratio of the $\mathrm{Co}_{1 \text { - }}$ ${ }_{x} \mathrm{Mg}_{\mathrm{x}} \mathrm{Fe}_{2} \mathrm{O}_{4}$ ferrite system for typical sample $\mathrm{x}=0.50$

TABLE I

Miller indices (h k 1), Bragg's angle (20), Interplanar spacing (d), Intensity (I) and Relative intensity ratio (I/Io) of $\mathrm{Co}_{1-x} \mathrm{Mg}_{\mathrm{x}} \mathrm{Fe}_{2} \mathrm{O}_{4}$ ( $\mathrm{x}=$

\begin{tabular}{|l|l|l|l|l|}
\hline$($ h k l) & $\begin{array}{l}\mathbf{2 \theta} \\
(\text { degree })\end{array}$ & $\begin{array}{l}\text { d } \\
(\AA)\end{array}$ & $\begin{array}{l}\text { I } \\
(\mathbf{a . u})\end{array}$ & $\mathbf{I} / \mathbf{I}_{\mathbf{O}}$ \\
\hline$(220)$ & 30.11 & 2.9656 & 1650.4 & 61 \\
\hline$(311)$ & 35.48 & 2.5277 & 2694.7 & 100 \\
\hline$(222)$ & 43.17 & 2.0936 & 1514.3 & 56 \\
\hline$(400)$ & 53.50 & 1.7112 & 1362.8 & 51 \\
\hline$(422)$ & 57.04 & 1.6130 & 1613.6 & 60 \\
\hline$(511)$ & 62.69 & 1.4806 & 1824.2 & 68 \\
\hline
\end{tabular}

Using the interplanar spacing (d) and the corresponding Miller indices, the lattice constant (a) of all the samples were calculated using standard relation,

$\mathrm{a}=\mathrm{d} \sqrt{ }\left(\mathrm{h}^{2}+\mathrm{k}^{2}+\mathrm{l}^{2}\right) \quad \AA$

where, $\mathrm{d}$ is interplanar spacing and (h k l) are Miller Indices.

The obtained values of the lattice constant ' $a$ ' are given in table 2. It is found that the lattice constant decreases with increase in magnesium content $\mathrm{x}$. The decrease in lattice constant is attributed to the difference in the ionic radii of $\mathrm{Co}^{2+}$ and $\mathrm{Mg}^{2+}$. The slight variation in lattice constant may be due to slight difference in the ionic radii of $\mathrm{Co}^{2+}(0.74$ Á) and $\mathrm{Mg}^{2+}(0.72 \AA \hat{A})$ ions.

The unit cell volume (V) for both the samples was calculated by using the following equation and is represented in table 2 .

$\mathrm{V}=\mathrm{a}^{3} \quad \AA \quad$...2

where, $\mathrm{V}$ is the unit cell volume and $\mathrm{a}$ is the lattice constant.

The unit cell volume (V) shows gradual decrease with the substitution of magnesium for cobalt in the present ferrite system. The decrease in cell volume is attributed to decrease in lattice constant of the system under investigation.

The values of lattice constant and molecular weight (table 2.) were used to determine the $X$-ray density for all the samples. By using the following relation [17], the X-ray density was calculated

$$
d_{x}=\frac{Z \times M}{V \times N_{A}}
$$

$\mathrm{gm} / \mathrm{cm}^{3} \quad \ldots 3$

where, $d_{x}$ is $\mathrm{X}$-ray density, $\mathrm{Z}$ is the number of molecules per unit, $\mathrm{M}$ is molecular mass of the sample, $\mathrm{V}$ is the unit cell volume and $\mathrm{N}_{\mathrm{A}}$ is the Avogadro's number.

Similar to lattice constant the X-ray density also decreases with increase in magnesium content $\mathrm{x}$. The decrease in $\mathrm{X}$ - 
ray density is attributed to the decrease in mass overtakes the decrease in volume. Also due to difference in their atomic weight $(\mathrm{Co}=58.933$ a.m.u. and $\mathrm{Mg}=24.312$ a.m.u.) respectively.

The bulk densities $\left(d_{B}\right)$ of all the samples were measured using Archimedes principle. The values of bulk density are reported in table 2 . It is found that bulk density decreases with increase in magnesium content $x$. The bulk density $d_{B}$ is less than X-ray density $\mathrm{d}_{\mathrm{x}}$. The small difference between these two density values is due to the existence of inter and intra granular porosity of the samples. Fig.4.4 shows the variation of bulk density with magnesium content $\mathrm{x}$.

The values of X-ray density, bulk density were used to obtain percentage porosity of all the samples in the following equation [17]:

$$
p=1-\frac{d_{b}}{d_{x}} \% \quad \quad \ldots 4
$$

where, $d_{b}$ is the bulk density and $d_{x}$ is the X-ray density.

The porosity of the present sample varies from $16 \%$ to $27 \%$.

The crystallite size of all the samples was calculated using Debye-Scherer's formula as given below [17]. The plane (311) with maximum intensity was considered for full width at half maxima (FWHM), the obtained values of crystallite size given in table 2 suggests that the prepared samples have nanocrystalline nature.

$$
t=\frac{0.9 \lambda}{\beta \cos \theta}
$$

$$
\mathrm{nm}
$$

where, $\lambda$ is wavelength of the $\mathrm{Cu}-\mathrm{K} \alpha$ radiation, $\beta$ is the full width of the half maximum and $\theta$ is Bragg's angle. The average particle size shown in Table 2 .

TABLE II

Lattice parameter $(\mathrm{a}), \mathrm{X}$-ray density $\left(\mathrm{d}_{\mathrm{x}}\right)$, Bulk density $\left(\mathrm{d}_{\mathrm{B}}\right)$, Porosity $(\mathrm{P}$ $\%)$, Unit cell volume (V) and Average particle size (t) of $\mathrm{Co}_{1-\mathrm{x}} \mathrm{Mg}_{\mathrm{x}} \mathrm{Fe}_{2} \mathrm{O}$

\begin{tabular}{|c|c|l|l|c|c|c|}
\hline $\mathbf{x}$ & $\begin{array}{c}\mathbf{a} \\
(\AA)\end{array}$ & $\begin{array}{c}\mathbf{d}_{\mathbf{x}} \\
\left(\mathbf{g m} / \mathbf{c m}^{\mathbf{3}}\right)\end{array}$ & $\begin{array}{c}\mathbf{d}_{\mathbf{B}} \\
\left(\mathbf{g m} / \mathbf{c m}^{\mathbf{3}}\right)\end{array}$ & $\begin{array}{c}\mathbf{P} \\
\mathbf{\%}\end{array}$ & $\begin{array}{c}\mathbf{V} \\
\left(\AA^{\mathbf{3}}\right)\end{array}$ & $\begin{array}{c}\text { Particle } \\
\text { size (t) }\end{array}$ \\
\hline 0.00 & 8.389 & 5.279 & 3.10 & 16.59 & 590.38 & 12.43 \\
\hline 0.50 & 8.373 & 4.916 & 3.27 & 23.88 & 587.11 & 24.13 \\
\hline 1.00 & 8.360 & 4.546 & 3.36 & 26.69 & 584.30 & 10.67 \\
\hline
\end{tabular}

Hopping length $\left(L_{A}\right.$ and $\left.L_{B}\right)$

The distance between magnetic ions called hopping length at tetrahedral (A) site and octahedral [B] site for all the samples was evaluated using the values of lattice constant by the following equations [18];

$$
\begin{array}{lll}
\mathrm{L}_{\mathrm{A}}=\mathrm{a} \sqrt{ }(3) / 4 & \AA & \ldots 6 \\
\mathrm{~L}_{\mathrm{B}}=\mathrm{a} \sqrt{ }(2) / 4 & \AA & \ldots 7
\end{array}
$$

The hopping lengths decrease as magnesium content $\mathrm{x}$ increases. The values of hopping length $\left(\mathrm{L}_{\mathrm{A}}\right.$ and $\left.\mathrm{L}_{\mathrm{B}}\right)$ are given in table 3 .

Using the experimental values of lattice constant ' $a$ ' and oxygen positional parameter ' $u$ ' $(u=0.381 \AA)$ other structural parameters such as tetrahedral bond length $\left(\mathrm{d}_{\mathrm{AX}}\right)$, octahedral bond length $\left(\mathrm{d}_{\mathrm{BX}}\right)$, tetra edge $\left(d_{\text {AXE }}\right)$ and octa edge $\left(d_{B X E}\right)$ were calculated for all the samples by using standard relations given below [18] and the values are tabulated in table 3 .

$$
\begin{aligned}
& \mathrm{d}_{\mathrm{AX}}=\mathrm{a}(3(\mathrm{u}-1 / 4))^{1 / 2} \quad \AA \quad \ldots 8 \\
& \mathrm{~d}_{\mathrm{BX}}=\mathrm{a}\left[3 \mathrm{u}^{2}-(11 / 4) \mathrm{u}+(43 / 64)\right]^{1 / 2} \quad \AA \quad \AA \quad \ldots 9 \\
& \mathrm{~d}_{\mathrm{AXE}}=\mathrm{a}[2(2 \mathrm{u}-1 / 2)]^{1 / 2}, \quad \AA ́ \\
& \mathrm{~d}_{\mathrm{BXE}}=\mathrm{a}[2(1-2 \mathrm{u})]^{1 / 2} \quad \AA \quad \AA .11 \\
& \mathrm{~d}_{\mathrm{BEU}}=\mathrm{a} \sqrt{ }\left(4 \mathrm{u}^{2}-3 \mathrm{u}+11 / 16\right) \quad \AA \quad \ldots 12
\end{aligned}
$$

It is evident from table 3 that the tetrahedral bond length, octahedral bond length, tetrahedral edge and octahedral edges decrease as magnesium content $\mathrm{x}$ increases. This is attributed to the decrease in lattice constant with the substitution of magnesium content $\mathrm{x}$.

TABLE III

Hopping length $\left(\mathrm{L}_{\mathrm{A}}, \mathrm{L}_{\mathrm{B}}\right)$, Tetrahedral bond $\left(\mathrm{d}_{\mathrm{AL}}\right)$, Octahedral bond $\left(\mathrm{d}_{\mathrm{BL}}\right)$, Tetra edge $\left(\mathrm{d}_{\mathrm{AE}}\right)$ and Octa edge $\left(\mathrm{d}_{\mathrm{BE}}\right)$ of $\mathrm{Co}_{1-\mathrm{x}} \mathrm{Mg}_{\mathrm{x}} \mathrm{Fe}_{2} \mathrm{O}_{4}$ system

\begin{tabular}{|c|c|c|c|}
\hline $\begin{array}{c}\text { Structural } \\
\text { Parameters }\end{array}$ & $\mathbf{x = 0 . 0}$ & $\mathbf{x}=\mathbf{0 . 5}$ & $\mathbf{x}=\mathbf{1 . 0}$ \\
\hline $\mathrm{L}_{\mathrm{A}}(\AA)$ & 3.632 & 3.625 & 3.619 \\
\hline $\mathrm{L}_{\mathrm{B}}(\AA)$ & 2.965 & 2.960 & 2.955 \\
\hline $\mathrm{d}_{\mathrm{AL}}(\AA)$ & 1.903 & 1.899 & 1.896 \\
\hline $\mathrm{d}_{\mathrm{BL}}(\AA)$ & 2.051 & 2.048 & 2.044 \\
\hline $\mathrm{d}_{\mathrm{AE}}(\AA)$ & 3.108 & 3.102 & 3.097 \\
\hline $\begin{array}{c}\mathrm{d}_{\mathrm{BE}} \\
\text { Shared } \mathrm{d}_{\mathrm{BE}}(\AA)\end{array}$ & 2.823 & 2.818 & 2.813 \\
\hline $\begin{array}{c}\mathrm{d}_{\mathrm{BE}} \\
\text { Unshared } \mathrm{d}_{\mathrm{BEU}} \\
(\AA)\end{array}$ & 2.967 & 2.961 & 2.957 \\
\hline
\end{tabular}

\section{IV.CONCLUSION}

The nanocrystalline $\mathrm{Co}_{1-\mathrm{x}} \mathrm{Mg}_{\mathrm{x}} \mathrm{Fe}_{2} \mathrm{O}_{4}(\mathrm{x}=0.0,0.50$ and 1.0) successfully synthesized by sol-gel auto combustion technique using AR grade metal nitrates and citric acid as a fuel. The X-ray diffraction results for the samples of $\mathrm{Co}_{1 \text { - }}$ ${ }_{x} \mathrm{Mg}_{\mathrm{x}} \mathrm{Fe}_{2} \mathrm{O}_{4}(\mathrm{x}=0.0,0.50$ and 1.0) showed the formation of single phase cubic spinel structure. The lattice constant is found to decrease with increasing $\mathrm{Mg}^{2+}$ concentration. The particle size of the samples calculated using the Debye Scherrer's formula was obtained in the range of 11-24 nm. The tetrahedral bond length, octahedral bond length, tetrahedral edge and octahedral edges decrease as magnesium content $x$ increases. Overall, the substitution of magnesium in cobalt ferrite influences the structural properties.

\section{REFERENCES}

[1]. J. Roelofs, A.Van Dillen, Y. K. de Jong, Catal. Today 60 (2000) 297-303.

[2]. S. Maensiri, C. Masingboon, B. Boonchom, S. Seraphin, Scr. Mater. 56 (2007) 797-800.

[3]. F. Prinetto, D.Tichit, R. Teissier, B. Coq., Catal. Today 55 (2000) 103-116.

[4]. S. Murcia-Mascaros, R.Navarrao, L. Gomez-Sainero, U. Costantio, M. Nocchetti, J. L. G.Fierro., J. Catal. 198 (2001) 338-347.

[5]. L. B. Kong, Z. W. Li, G. Q. Lin, Y. B. Gan, J. Amer. Cer. Soc. 90 (2007) 2104.

[6]. Y. Konseoglu, H. Kavas, B. Aktas, Phys. Stat. Sol. A 203 (2003) 1595.

[7]. M. H. Khedr, A. A. Omar, M. I. Nasr, E. K. Sedeek, J. Anal. Appl. Pyroly. 76 (2006) 203.

[8]. J. F. Hochepied, M. P. Pileni, J. Appl. Phys. 87 (2000) 2472.

[9]. S. Sarkar, C. Bansal, R. Nagarajan, Condens. Matter 3 (2002) 207095.

[10]. L. J. Zhao, Q.Jiang, J. Magn. Magn. Mater. 322 (2010) 2485.

[11]. M. Manjurul Haque, M.Huq, M.A.Hakim, Physica B 404 (2009) 3915

[12]. A. Goldman, Modern Ferrite Technology (New York, Marcel Dekker, 1993).

[13]. S. H. Keluskar, R. B. Tangsali, G. K. Naik, J. S. Budkuley, J. Magn. Magn. Mater. 305, 296 - 303 (2006). 
[14]. S. G. Algude, S. M. Patange, S. E. Shirsath, D. R. Mane, K. M. Jadhav, J. Magn. Magn. Mater. 350 (2014) 39-41.

[15]. Nalla Somaiah, T. V. Jayaraman, P. A. Joy, Dibakar Das, J. Magn. Magn. Mater. 324:14 (2012) 2286-2291.

[16]. Santi Phumying, Sumalin Phokha, Santi Maensiri, J. Supercond. Nov. Magn. (2014) 27:2573-2579.

[17]. Elements of X-ray diffraction by B. D. Cullity, 1956 AddisonWesley, Publishing company, Inc.

[18]. Azadeh Najafi Birgani, Mohammad Niyaifar, Ahmad Hasanpour, J. Magn. Magn. Mater. 374 (2015) 179-181.

\section{BIOGRAPHIES}

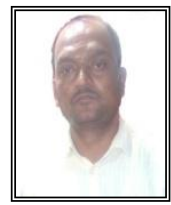

Mr. Vithal Vinayak(M.Sc., M.Phil., B.Ed.)

Asst. Professor,

Department of Chemistry,

B.S.S. Arts \& Science College,

Makni, Tq:Lohara,

Osmanabad (M.S.),India.

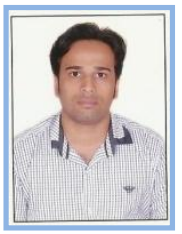

Mr. Pankaj P. Khirade (M.Sc., B.Ed.)

Research Student Department of Physics,

Dr.Babasaheb Ambedkar Marathwada University,

Aurangabad (M.S.), India.

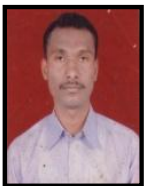

Mr. Shankar D. Birajdar (M.Sc., M.Phil, B.Ed.)

Research Student,

Department of Physics,

Dr.Babasaheb Ambedkar Marathwada University,

Aurangabad (M.S.), India

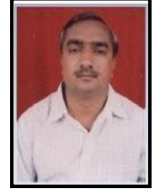

Prof. (Dr.) K. M. Jadhav, (M.Sc., Ph.D., B.Ed.)

Professor and Former Head,

Department of Physics,

Dr.Babasaheb Ambedkar Marathwada University,

Aurangabad (M.S.), India 